\title{
ЗМІНИ КИСНЕВОГО ЗАБЕЗПЕЧЕННЯ ПЕРИФЕРІЙНИХ ТКАНИН У ХВОРИХ НА ХРОНІЧНУ ЛІМФОБЛАСТНУ ЛЕЙКЕМІЮ В УМОВАХ КОМОРБІДНОСТІ
}

\author{
๑А. І. Хоміцька, Н. В. Пасєчко, Л. В. Радецька, А. О. Боб \\ Тернопільський національний медичний університет імені І. Я. Горбачевського МОЗ України
}

РЕЗЮМЕ. Кисневе забезпечення периферійних тканин та його порушення $є$ надзвичайно важливим механізмом у виникненні багатьох захворювань та їх прогресуванні. Вивчення механізмів та діагностичних критеріїв порушень кисневого забезпечення тканин організму у хворих на онкогематологічні заворювання в умовах коморбідності може сприяти розробці методів корекції виявлених змін.

Мета - оцінити стан кисневого забезпечення периферійних тканин у хворих на хронічну лімфобластну лейкемію із супутньою стабільною ішемічною хворобою серця.

Матеріал і методи. Кисневе забезпечення периферійних тканин оцінювали за допомогою показників оксигенації артеріальної та венозної крові: сатурація артеріальної крові $\left(\mathrm{Sa}_{2} \mathrm{O}_{2}\right)$, сатурація венозної крові (Sv.O2) вміст кисню в артеріальній крові (Са.О $)$, вміст кисню у венозній крові (Cv.O $\left.{ }_{2}\right)$, а також об'єм кисню, спожитого периферійними тканинами (Da.O - Dv. $\mathrm{O}_{2}$ ). Дані показники визначали методом пульсоксиметрії та оксиметрії.

Результати. У хворих на хронічну лімфобластну лейкемію із супутньою стабільною ішемічною хворобою серця виявлено виражені порушення кисневого забезпечення периферійних тканин із достовірним зниженням сатурації венозної крові, вмісту кисню в артеріальній крові та об'єму кисню, спожитого периферійними тканинами, у порівнянні із обстеженими хворими на хронічну лімфобластну лейкемію без супутньої стабільної ішемічної хвороби серця.

Висновки. У хворих на хронічну лімфобластну лейкемію із супутньою стабільною ішемічною хворобою серця виявлено виражені порушення оксигенації артеріальної та венозної крові, що підтверджується достовірним зниженням сатурації венозної крові Sv.O $(p<0,01)$, вмісту кисню в артеріальній крові Са.О 2 ( $<<0,01)$ та о6'єму кисню, спожитого периферійними тканинами Da.O $-\mathrm{Dv}_{2} \mathrm{O}_{2}(\mathrm{p}<0,05)$, порівняно з хворими на хронічну лімфобластну лейкемію без супутньої ішемічної хвороби серця. Виявлені зміни можуть бути свідченням суттєвого зниження кисневого забезпечення периферійних тканин при прогресуванні основного захворювання в умовах коморбідності.

КЛючОВІ СЛОВА: хронічна лімфобластна лейкемія; стабільна ішемічна хвороба серця; кисневе забезпечення периферійних тканин; сатурація артеріальної крові; сатурація венозної крові.

Вступ. Розлади кисневого гомеостазу характеризуються невідповідністю між потребою організму в кисні та його спроможністю забезпечити ці потреби $[2,7]$. Це $\epsilon$ одним із визначальних факторів порушення тканинного метаболізму і функцій клітин при критичних станах і, в кінцевому стані, танатогенезу [1, 2].

Як відомо, гіпоксія визначає тяжкість перебігу основних захворювань, патологій судин головного мозку, формування поліорганної недостатності при шокових та колаптоїдних станах [2], $\epsilon$ незмінним супутником захворювань інфекційного та неінфекційного ґенезу [5], а також стресових станів [4]. При онкогематологічних захворюваннях виникає гемічна гіпоксія, яка призводить до порушень серцево-судинної діяльності, що характеризуються змінами біоелектричної активності та прогресуванням проявів серцевої недостатності $[3,7]$. Порушення балансу в системі кисневого забезпечення при онкогематологічних захворюваннях може бути однією з причин прогресування основного захворювання [6] та неадекватної відповіді на лікування, проте дослідження в даному напрямку $\epsilon$ досить обмеженими.

Мета - оцінити стан кисневого забезпечення периферійних тканин у хворих на хронічну лімфо- бластну лейкемію із супутньою стабільною ішемічною хворобою серця.

Матеріал і методи дослідження. У пацієнтів із хронічною лімфобластною лейкемією (ХЛЛ, $\mathrm{n}=62$ ) оцінювали кисневе забезпечення периферійних тканин. Усі обстежені були поділені на групи залежно від наявності коморбідного стану стабільної ішемічної хвороби серця (IXC): 1 група - хворі на ХЛЛ без IXC ( $n=30) ; 2$ група - хворі на ХЛЛ із супутньою стабільною IXC ( $n=32)$. До контрольної групи увійшли 30 здорових осіб, зіставних за віком та статтю.

Оскільки основний об'єм кисню (180-200 мл·л"1) транспортується до периферійних тканин у сполученні з гемоглобіном $(\mathrm{Hb})$, і лише незначна його частина (3 мл·л $\left.{ }^{-1}\right)$ розчинена у плазмі, основними показниками повноцінності транспортування кисню до тканин організму $\epsilon$ насиченість Нb артеріальної (Sa.O $)_{2}$ та венозної крові (Sv.O $)$ киснем та вміст кисню в артеріальній $\left(\mathrm{Ca}_{2} \mathrm{O}_{2}\right)$ та венозній крові (Cv. $\left.\mathrm{O}_{2}\right)$, а також об'єм кисню, спожитого периферійними тканинами $\left(\mathrm{Da} . \mathrm{O}_{2}-\mathrm{Dv} . \mathrm{O}_{2}\right)[1,2]$.

$\mathrm{Sa} . \mathrm{O}_{2}$ визначали за допомогою пульсоксиметра за загальноприйнятою методикою. Визначення Sv.O проводили in vitro за допомогою апарата «Oxymeter Unistat». 
Огляди літератури, оригінальні дослідження, погляд на проблему, випадок з практики, короткі повідомлення

Визначення Са.О, проводили за наступною формулою:

$$
\text { Ca. } \mathrm{O}_{2}=\mathrm{Sa} . \mathrm{O}_{2} \times \mathrm{Hb} \times 1,34 .
$$

Визначення Cv. ${ }_{2}$ проводили за наступною формулою:

$$
\mathrm{Cv} \cdot \mathrm{O}_{2}=\mathrm{Sv} \cdot \mathrm{O}_{2} \times \mathrm{Hb} \times 1,34 \text {. }
$$

Різниця між об'ємами кисню, який міститься в 1 л артеріальної та змішаної венозної крові, вказувала на об'єм кисню, спожитого периферійними тканинами для забезпечення метаболічних потреб організму (Da.O $\left.\mathrm{O}_{2}-\mathrm{Dv} . \mathrm{O}_{2}\right)$.

Результати й обговорення. Оцінка показників оксигенації артеріальної та венозної крові пока- зала, що у хворих на ХЛЛ із супутньою стабільною IXC відмічалося деяке зниження Sa.O (на 5,3 \%, $\mathrm{p}<0,05)$, порівняно з контрольною групою (табл. 1). Значення Sv. ${ }_{2}$ у хворих на ХЛЛ та стабільну IXС достовірно знижувалося на $25,2 \%(p<0,01)$, порівняно з групою контролю. Вміст кисню в артеріальній

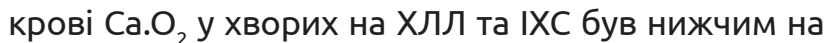
$19,2 \%(p<0,01)$, порівняно з групою контролю. У пацієнтів цієї групи виявлено зниження значення Cv. $\mathrm{O}_{2}$ на $22,1 \%(p<0,01)$, порівняно із здоровими особами. Відповідно, об'єм кисню, спожитого периферійними тканинами Da.O - -Dv. $\mathrm{O}_{2}$, був нижчим на $11,9 \%(p<0,05)$, ніж у групі контролю.

Таблиця 1. Показники оксигенації артеріальної та венозної крові у хворих на ХЛЛ із супутньою стабільною IXС

\begin{tabular}{|c|c|c|c|c|}
\hline Показник & $\begin{array}{c}\text { Контрольна група, } \\
\text { n=30 }\end{array}$ & $\begin{array}{c}1 \text { група, } \\
\mathrm{n}=30\end{array}$ & $\begin{array}{c}2 \text { група, } \\
\mathrm{n}=32\end{array}$ & $P_{1-2}$ \\
\hline $\mathrm{Sa} \mathrm{O}_{2}, \%$ & $98,40 \pm 0,41$ & $94,12 \pm 0,74$ & $92,53 \pm 0,51 *$ & $>0,05$ \\
\hline $\mathrm{Sv} \mathrm{O}_{2}, \%$ & $70,31 \pm 0,33$ & $60,26 \pm 0,41 *$ & $52,64 \pm 0,58 *$ & $<0,01$ \\
\hline $\begin{array}{l}\text { Са.O }{ }^{\prime}{ }^{\prime} \\
\text { мл·л }{ }^{-1}\end{array}$ & $149,20 \pm 0,62$ & $140,10 \pm 1,53^{*}$ & $120,57 \pm 2,65^{*}$ & $<0,01$ \\
\hline $\begin{array}{l}\mathrm{Cv.O}_{2 \prime} \\
\text { мл•л }{ }^{-1}\end{array}$ & $98,33 \pm 0,62$ & $92,13 \pm 1,41 *$ & $76,75 \pm 2,57 *$ & $<0,01$ \\
\hline $\begin{array}{l}\text { Da.O }{ }_{2}-\mathrm{Dv} \cdot \mathrm{O}_{2} \\
\text { мл·л }\end{array}$ & $50,96 \pm 0,66$ & $47,97 \pm 0,62$ & $43,82 \pm 0,84 *$ & $<0,05$ \\
\hline
\end{tabular}
$(\mathrm{M} \pm \mathrm{m})$

Примітки: 1. * - достовірність різниці показників порівняно з контролем; 2. р1-2 - достовірність різниці показників між групами хворих.

Порівнюючи параметри оксигенації артеріальної та венозної крові у хворих обох груп, було відмічено, що у хворих на ХЛЛ із супутньою стабільною IXC відмічалося більш суттєве зниження даних показників, порівняно із хворими на ХЛЛ без IXC. Зокрема, значення Sa.O було дещо нижчим у групі хворих на ХЛЛ із стабільною IXC, порівняно із хворими 1 групи. Значення Sv.O при коморбідності ХЛЛ та стабільної IXС було нижчим на $14,8 \%(p<0,01)$, порівняно з хворими на ХЛЛ. Значення Сa.O $\mathrm{i} \mathrm{Cv}_{2} \mathrm{O}_{2}$ були значимо нижчими у групі хворих на ХЛЛ при супутній стабільній IXC, що $\epsilon$ свідченням недостатнього насичення киснем периферійних тканин в результаті утруднення трансвенозного кровотоку.

Об'єм кисню, спожитого периферійними тканинами, Da.O - Dv. ${ }_{2}$ у хворих на ХЛЛ із супутньою IXC у був нижчим на $15,2 \%(p<0,05)$, порівняно $з$ контрольною групою, та на $10,6 \%(p<0,05)$ порівняно 3 хворими без супутньої IXC. При приєднанні коморбідної патології, а саме стабільної IXC, відбувається прогресування феномену кисневої заборгованості, тобто на фоні клінічних ознак ХЛЛ зниження вмісту кисню та насиченості ним венозної крові можуть слугувати критеріями прогресування як основної, так і коморбідної патології.
Отже, у хворих на ХЛЛ із супутньою стабільною IXC виникають комплексні порушення кисневого балансу: на етапі надходження кисню в організм, його сполучення з $\mathrm{Hb}$, транспортування до тканин та включення у метаболічні реакції. Ці порушення значною мірою зумовлені змінами функціональної здатності міокарда, які корелюють із зниженням кисневого забезпечення периферійних тканин.

Висновки. 1. У хворих на ХЛЛ із супутньою стабільною IXC виявлено значні порушення оксигенації артеріальної та венозної крові, що підтверджується достовірним зниженням сатурації венозної крові Sv. $\mathrm{O}_{2}(p<0,01)$ та вмісту кисню в артеріальній крові Са.О $(p<0,01)$.

2. Об'єм кисню, спожитого периферійними тканинами, Da.O - Dv.O 2 був достовірно нижчим $(p<0,05)$ у пацієнтів із ХЛЛ та супутньою стабільною IXC, порівняно з хворими на ХЛЛ без IXC.

3. Виявлені порушення можуть слугувати свідченням суттєвого зниження кисневого забезпечення периферійних тканин при прогресуванні ХЛЛ в умовах коморбідності.

Перспективи подальших досліджень. Планується провести корекцію виявлених порушень кисневого забезпечення периферійних тканин у хворих на ХЛЛ в умовах коморбідності зі стабільною IXC. 
Огляди літератури, оригінальні дослідження, погляд на проблему, випадок з практики, короткі повідомлення ЛІТЕРАТУРА

1. Балабан А. І. Діастолічна дисфункція і кисневе забезпечення тканин та їх корекція при стабільній стенокардії напруги із супутнім цукровим діабетом 2 типу : дис. на здобуття наук. ступеня канд. мед. наук: 14.01.02/ Балабан Алла Іванівна. - Т., 2016. - 236 с.

2. Гнатів В. В. Системний і реґіонарний кисневий баланс та периопераційна інтенсивна терапія при ускладнених формах виразкової хвороби шлунка і дванадцятипалої кишки: дис. на здобуття наук. ступеня д-ра мед. наук: 14.01.30 / Гнатів Володимир Володимирович.-Д., 2006. -345 c.

3. Хоміцька А. І. Порушення кисневого забезпечення периферійних тканин при анемії хронічних захворювань / А. І. Хоміцька, А. О. Боб, Г. Г. Кміта // Здобутки

клінічної та експериментальної медицини. - 2018. № 2. - С. 144-146.

4. Essop M. F. Cardiac metabolic adaptations in response to chronic hypoxia / M. F. Essop // J. Physiol. - 2017. No. 3. - P. 715-726.

5. George J. Circulating erythropoietin levels and prognosis in patients woth congestive heart failure / J. George // Arch. Intern. Med. - 2015. - Vol. 165 (11). - P. 1304-1309.

6. Naeije R. Physiological adaptation of the cardiovascular system to high altitude / R. Naeije // Prog. Cardiovasc. Dis. - 2010. - No. 6. - P. 456-466.

7. Stockman C. Hypoxia-induced erythropoietin: a paradigm for oxygen-regulated gene expression / C. Stockman // Clin. Exp. Physiol. Pharmacol. - 2016. - No. 10. - P. 968-979.

\title{
REFERENCES
}

1. Balaban, A.I. (2016). Diastolichna dysfunktsiia $\mathrm{i}$ kysneve zabezpechennia tkanyn ta yikh korektsiia pry stabilnii stenokardii napruhy iz suputnim tsukrovym diabetom 2 typu [The diastolic dysfunction and oxygen supply of the tissues and its correction in patients with stable ischemic heart disease and concomitant type 2 diabetes mellitus]. Candidate's thesis. Ternopil [in Ukrainian].

2. Hnativ, V.V. (2006). Systemnyi i rehionarnyi kysnevyi balans ta peryoperatsiina intensyvna terapiia pry uskladnenykh formakh vyrazkovoi khvoroby shlunka i dvanatsiatypaloi kyshky [The systemic and regional balance and perioperation intensive therapy of the complicated forms of peptic ulcer disease]. Candidate's thesis. Dnipropetrovsk [in Ukrainian].

3. Khomitska, A.I. (2018). Porushennia kysnevoho zabezpechennia peryferiinykh tkanyn pry anemii khronichnykh zakhvoriuvan [The violations of the oxygen supply of

peripheral tissues in patients with anemia of chronic diseases]. Zdobutky klinichnoi ta eksperymentalnoi medytsyny - Achievements of Clinical and Experimental Medicine, 2, 144-146 [in Ukrainian].

4. Essop, M.F. (2017). Cardiac metabolic adaptations in response to chronic hypoxia. Journal of Physiology, 3, 715-726.

5. George, J. (2015). Circulating erythropoietin levels and prognosis in patients woth congestive heart failure. Archives Internal Medicine, 11, 1304-1309 [in Ukrainian].

6. Naeije, R. (2010). Physiological adaptation of the cardiovascular system to high altitude. Progressive Cardiovascular Disease, 6, 456-466.

7. Stockman, J. (2016). Hypoxia-induced erythropoietin: a paradigm for oxygen-regulated gene expression. Clinical Experimental Physiological Pharmacology, 10, 968-979.

\section{ИЗМЕНЕНИЯ КИСЛОРОДНОГО ОБЕСПЕЧЕНИЯ ПЕРИФЕРИЧЕСКИХ ТКАНЕЙ У БОЛЬНЫХ ХРОНИЧЕСКОЙ ЛИМФОБЛАСТНОЙ ЛЕЙКЕМИЕЙ В УСЛОВИЯХ КОМОРБИДНОСТИ}

\author{
๑А. И. Хомицкая, Н. В. Пасечко, Л. В. Радецкая, А. О. Боб
}

Тернопольський национальный медицинский университет имени И. Я. Горбачевского МОЗ Украины

РЕзЮМЕ. Кислородное обеспечение периферических тканей и его нарушение является чрезвычайно важным механизмом в возникновении многих заболеваний и их прогрессировании. Изучение механизмов и диагностических критериев нарушений кислородного обеспечения тканей организма у больных онкогематологическими заболеваниями в условиях коморбидности может способствовать разработке методов коррекции выявленных изменений.

Цель - оценить состояние кислородного обеспечения периферических тканей у больных хронической лимфобластной лейкемией с сопутствующей стабильной ишемической болезнью сердца.

Материал и методы. Кислородное обеспечение периферических тканей оценивали при помощи показателей оксигенации артериальной и венозной крови: сатурация артериальной крови (Sa.O $)_{2}$, сатурация венозной крови (Sv. $\left.\mathrm{O}_{2}\right)$, содержание кислорода в артериальной крови (Са.О $)_{2}$, содержание кислорода в венозной крови $\left(\mathrm{Cv} . \mathrm{O}_{2}\right)$, а также объем кислорода, потребленного периферическими тканями (Da.O - Dv.O 2 ). Данные показатели изучали методом пульсоксиметрии и оксиметрии.

Результаты. У больных хронической лимфобластной лейкемией и сопутствующей стабильной ишемической болезнью сердца обнаружены выраженные нарушения кислородного обеспечения периферических тканей с 
Огляди літератури, оригінальні дослідження, погляд на проблему, випадок з практики, короткі повідомлення достоверным снижением сатурации венозной крови, содержания кислорода в артериальной крови и объема кислорода, потребленного периферическими тканями, в сравнении с обследованными больными хронической лимфобластной лейкемией без сопутствующей стабильной ишемической болезни сердца.

Выводы. У больных хронической лимфобластной лейкемией и сопутствующей стабильной ишемической болезнью сердца обнаружены выраженные нарушения оксигенации артериальной и венозной крови, что подтверждается достоверным снижением сатурации венозной крови Sv.O $(p<0,01)$, содержания кислорода в артериальной крови Сa.O $(p<0,01)$ и объема кислорода, потребленного периферическими тканями Da.O - Dv.O 2 $(p<0,05)$, в сравнении с пациентами с хронической лимфобластной лейкемией без сопутствующей ишемической болезни сердца. Обнаруженные изменения могут быть свидетельством существенного снижения кислородного обеспечения периферических тканей при прогрессировании основного заболевания в условиях коморбидности.

КЛЮЧЕВЫЕ СЛОВА: хроническая лимфобластная лейкемия; стабильная ишемическая болезнь сердца; кислородное обеспечение периферических тканей; сатурация артериальной крови; сатурация венозной крови.

\title{
THE CHANGES OF OXYGEN SUPPLY OF PERIPHERAL TISSUES IN PATIENTS WITH CHRONIC LYMPHOBLASTIC LEUKEMIA IN CONDITIONS OF COMORBIDITY
}

\author{
๑A. I. Khomitska, N. V. Pasyechko, L. V. Radetska, A. O. Bob \\ I. Horbachevsky Ternopil National Medical University
}

SUMMARY. The oxygen supply of the peripheral tissues and its violations are the most important mechanisms in the emergence of the many diseases and its progression. The studying of the mechanisms and diagnostic criteria of the oxygen supply violations of tissues in patients with oncohematological diseases in conditions of comorbidity can contribute to development of correction methods of the detected changes.

The aim of the study - to evaluate the state of the oxygen supply of peripheral tissues in patients with chronic lymphoblastic leukemia and concomitant stable ischemic heart disease.

Material and Methods. The oxygen supply of the peripheral tissues was evaluated by the indixes of arterial and venous blood oxygenation: the arterial blood saturation ( $\left.\mathrm{Sa}_{2} \mathrm{O}_{2}\right)$, the venous blood saturation ( $\left.\mathrm{Sv} . \mathrm{O}_{2}\right)$, the oxygen content in the arterial blood ( $\left.\mathrm{Ca}_{2} \mathrm{O}_{2}\right)$, the oxygen content in the venous blood $\left(\mathrm{Cv} \mathrm{O}_{2}\right)$ and also the oxygen volume consumption by the peripheral tissues ( $\mathrm{Da} . \mathrm{O}_{2}-\mathrm{Dv} . \mathrm{O}_{2}$ ). This index was determined by the pulse oximetry and oximetry methods.

Results. There was an expressed violations of the oxygen supply of the peripheral tissues in patients with chronic lymphoblastic leukemia and concomitant stable ischemic heart disease, that detected by the certainty decreasing of the venous blood saturation, the oxygen content in the arterial blood and the oxygen volume consumption by the peripheral tissues compared with the inspected patients with chronic lymphoblastic leukemia without concomitant stable ischemic heart diseases.

Conclusions. There was the significant violations of the arterial and venous oxygenation in patients with chronic lymphoblastic leukemia and concomitant stable ischemic heart disease, that detected by the certainty decreasing of the venous blood saturation $\mathrm{Sv}_{\mathrm{O}} \mathrm{O}_{2}(\mathrm{p}<0,01)$, the oxygen content in the arterial blood Ca.O $(p<0,01)$ and also the oxygen volume consumption by the peripheral tissues $\mathrm{Da}_{2} \mathrm{O}_{2}-\mathrm{Dv}_{\mathrm{O}} \mathrm{O}_{2}(\mathrm{p}<0,05)$, compared with patients with chronic lymphoblastic leukemia without concomitant stable ischemic heart disease. This violations can be a sign of the pronounced decreasing of the oxygen supply of peripheral tissues in the progressing of the main disease in conditions of comorbidity.

KEY WORDS: chronic lymphoblastic leukemia; stable ischemic heart disease; oxygen supply of the pheripheral tissues; arterial blood saturation; venous blood saturation.

Отримано 6.05.2019 